\title{
Decay Resistance and Color Change of Pine and Beech Wood Impregnated with $R$. Luteum and R. Ponticum Plant Extracts
}

\section{Otpornost borovine i bukovine impregnirane ekstraktima biljaka $R$. luteum i $R$. ponticum na propadanje i promjenu boje}

\author{
Original scientific paper • Izvorni znanstveni rad \\ Received-prispjelo: 11. 11. 2020. \\ Accepted-prihvaćeno: 26. 5. 2021. \\ UDK: $630 * 841.51 ; 630 * 841.63$ \\ https://doi.org/10.5552/drvind.2021.2043
}

(C) 2021 by the author(s). Licensee Faculty of Forestry and Wood Technology, University of Zagreb. This article is an open access article distributed under the terms and conditions of the Creative Commons Attribution (CC BY) license.

\begin{abstract}
In this study, the effect of impregnation with natural extracts on decay resistance and color change of pine and beech wood was analyzed. Flowers of Rhododendron luteum and Rhododendron ponticum plants were extracted according to the decoction method and aqueous solutions were prepared at different concentration levels $(2 \%, 4 \%$ and $7 \%)$. In addition, ferrous sulfate, copper sulfate and aluminum sulfate mordants were added to the solution to improve the properties of the extracts. Then the wood specimens were impregnated with the prepared solutions. The results indicated that the effect of plant species on the mass loss of specimens exposed to T. versicolor (white-rot fungus) was insignificant. Non-mordant extracts had a slight effect on the mass loss of the specimens. However, in pine and beech specimens impregnated with mordant-added (especially ferrous sulfateadded) extracts, mass loss was significantly reduced and resistance to fungal rot was almost completely achieved. The concentration level did not have a significant effect on the mass loss of specimens treated with mordant-added extracts. After impregnation, the $L^{*}$ value of all specimens (especially those treated with ferrous sulfate-added extracts) decreased and the specimens darkened. The $a^{*}$ and $b^{*}$ values increased in specimens treated with nonmordant and aluminum sulfate-added extracts and these specimens tend to have a red-yellow color. The a*value decreased and the $b^{*}$ value increased in wood specimens treated with copper sulfate-added extracts. The greenyellow color trend of these specimens increased. Both the $a^{*}$ and $b^{*}$ values of the specimens treated with ferrous sulfate-added extracts decreased and the green-blue color tendency increased in these specimens. The increase in the concentration level positively affected the determined color changes. The total color change $\left(\Delta E^{*}\right)$ was higher in wood specimens (especially pine) treated with ferrous sulfate-added $\underline{R}$. ponticum extracts.
\end{abstract}

Keywords: color change; decay resistance; impregnation; natural extract; wood material

SAŽETAK •U istraživanju je analiziran utjecaj impregnacije borovine i bukovine biljnim ekstraktima na otpornost na propadanje. Cvjetovi biljaka Rhododendron luteum $i$ Rhododendron ponticum ekstrahirani su metodom dekocije te su pripremljene vodene otopine različitih koncentracija (2\%, $4 \%$ i $7 \%$ ). Osim toga, otopini su dodani fiksatori željezov sulfat, bakrov sulfat $i$ aluminijev sulfat radi poboljšanja svojstava ekstrakata. Zatim su uzorci

${ }^{1}$ Authors are researchers at Duzce University, Faculty of Forestry, Department of Wood Products Industrial Engineering, Duzce, Turkey.

${ }^{2}$ Author is researcher at Duzce University, Faculty of Forestry, Department of Forest Products Engineering, Duzce, Turkey. 
drva impregnirani pripremljenim otopinama. Rezultati su pokazali da je utjecaj vrste biljke na gubitak mase uzoraka izloženih djelovanju T. versicolor (gljivi bijele truleži) bio neznatan. Ekstrakti bez fiksatora imali su mali učinak na gubitak mase uzoraka. Međutim, znatno je smanjen gubitak mase uzoraka borovine i bukovine impregniranih ekstraktima s dodatkom fiksatora (osobito željezova sulfata), a postignuta je gotovo potpuna otpornost na gljive truležnice. Koncentracija otopine nije imala znatniji utjecaj na gubitak mase uzoraka zaštićenih ekstraktima s dodatkom fiksatora. Nakon impregnacije smanjila se $L^{*}$ vrijednost svih uzoraka (posebno onih zaštićenih ekstraktima s dodatkom željezova sulfata) i uzorci su potamnjeli. Povećale su se vrijednosti a* $i b^{*}$ uzoraka impregniranih ekstraktima bez dodatka fiksatora i ekstraktima s dodatkom aluminijeva sulfata i ti su uzorci poprimili crvenožutu boju. Vrijednost a* uzoraka drva premazanih ekstraktima s dodatkom bakrova sulfata smanjila se, a vrijednost $b^{*}$ se povećala. Udio žutozelene komponente na tim se uzorcima povećao. Vrijednosti a* $i b^{*}$ uzoraka premazanih ekstraktima s dodatkom željezova sulfata smanjile su se i povećao se udio zelenoplave komponente. Povećanje koncentracije otopine kojom su uzorci impregnirani pozitivno je utjecalo na promjenu boje. Ukupna promjena boje $\left(\Delta E^{*}\right.$ ) bila je veća na uzorcima drva (osobito borovim) impregniranim ekstraktima $\underline{R}$. ponticum $s$ dodatkom željezova sulfata.

Ključne riječi: promjena boje; otpornost na propadanje; impregnacija; prirodni ekstrakt; drvni materijal

\section{INTRODUCTION}

\section{UVOD}

Wood materials are structural materials that can generally degrade under the influence of biotic and abiotic factors. Therefore, this material, which has a certain service life, can be made resistant to biological, physical and chemical factors, and its technical and economic losses can be reduced or eliminated completely. For this purpose, methods such as impregnation, upper surface treatments and various modification processes are used for the protection of wood. Among these methods, deep impregnation of organic or inorganic based biocides into wood is highly preferred from past to present.

With the increasing environmental awareness in recent years, the restriction or complete prohibition of the use of inorganic based preservative salts has increased the interest in the development of environmentally friendly preservatives in the field of wood protection. In this context, one of the subjects that are considered as a scientific alternative and studied scientifically is herbal extracts and tannins (Goktas et al., 2008; Tascioglu et al., 2013; Broda, 2020). These extractives are compounds that naturally protect wood from biological degradation (Toshiaki, 2001; Windeisen et al., 2002; Kartal et al., 2006; Lin et al., 2007; Goktas et al., 2010; Ozen et al., 2014; Colak, 2016). In addition, extracts can affect the color, odor, drying, adhesion, water absorption and acoustic properties of wood (Tanaka et al., 2008). Extracts can be found in various parts of plants such as bark, wood, fruit, flower, leaf, and root (Onal, 2000). Extractives can be obtained from plants through cold water, hot water, and soxhlet extraction and with the aid of different solvents such as hexane, dichloromethane, toluene/ethanol mixture or water (Toshiaki, 2001).

Wood materials need to be colored in different tones other than their natural color, both in line with user requests and in order to ensure a homogeneous color harmony (Sonmez, 2005). To meet this need, natural and environmentally friendly extractives have the potential to be an important alternative (Onal, 2000). Synthetic-based dyes can cause some serious health problems such as allergic reactions and carcinogenicity due to their toxicity and non-biodegradable nature (Prabhu and Bhute, 2012). The use of natural dyes has further increased substantially over the current years, with a slow but growing revival phase at present, due to people's concern over reducing environmental pollution and hence to avoid chemically more hazardous synthetic dyes and intermediates (Samanta, 2020).

The most important problem encountered in impregnation of wood with plant extracts is the potential of these polyphenols to be washed with water from the wood. Fixation of extracts to wood is an important issue as extracts usually dissolve when exposed to high humidity or in contact with water. Therefore, the extracts are used together with various inorganic substances (boron, copper, aluminum compounds, etc.) (Yamaguchi, 2001, Thevenon et al., 2009; Tondi et al., 2012). Mordants are used to increase the binding of natural extracts to functional groups in wood material and for different color options. Ferrous sulfate, copper sulfate and aluminum sulfate are metal salts and they are the most widely used mordants for natural extracts derived from plants (Yeniocak et al., 2018). Metal mordants contribute to developing wide gamut of hues after complexing with natural coloring compounds. Most of these are toxic in nature, but their presence in trace quantity has been found to be safe for users (Prabhu and Bhute, 2012).

Rhododendrons are perennial plants and belong to the Ericaceae family. More than 850 species of Rhododendron L. are distributed in the Northern Hemisphere. The genus Rhododendron distributed in North Eastern and West Anatolia is represented by 9 species, two being endemic and altogether 12 taxa, 4 hybrids and 1 form (Stevens, 1978; Terzioglu et al., 2001; Kucuk et al., 2018). R. ponticum and R. luteum among these species are widely spread in Turkey (Kucuk, 2005; Birinci et al., 2020). The flowers of $R$. ponticum, which bloom between March and May, are purplish pink and have plenty of nectar. The flowers of $R$. luteum, which bloom between April and September, are yellow and have plenty of nectar (Stevens, 1978; Ceter and Guney, 2011). Rhododendron species contain 
Grayanotoxin (Andromedotoxin, Acebotoxin, Acetylandromedol, Rhodotoxin) in diterpene structure as a poisonous compound in leaves, flowers, nectar and pollens (Kucuk, 2005). Honey from the flowers of Rhododendron is locally known as "'deli bal, acı bal, tutar bal" (mad honey). Rhododendron is used for therapeutic purposes as a medicinal herb due to its positive effects on stomach-bowel ailments, skin diseases, asthma, pain and colds. Rhododendron species is also used as an ornamental plant due to its showy flowers (Kucuk et al., 2018; Akgun, 2019).

The objective of this study is to investigate the wood material protection efficiency and coloring potential of impregnation solutions prepared from $R$. $l u$ teum and $R$. ponticum plant extracts at different concentration levels. In addition, the effects of ferrous sulfate $\left(\mathrm{Fe}_{2}\left(\mathrm{SO}_{4}\right)_{3} \times 7 \mathrm{H}_{2} \mathrm{O}\right)$, copper sulfate $\left(\mathrm{CuSO}_{2} \times 5 \mathrm{H}_{2} \mathrm{O}\right)^{2}$ and aluminum sulfate $\left(\mathrm{KAl}_{2}\left(\mathrm{SO}_{4}\right)_{3} \times 18 \mathrm{H}_{2} \mathrm{O}\right)$ mordants added to impregnation solutions on selected properties were analyzed.

\section{MATERIALS AND METHODS}

\section{MATERIJALI I METODE}

\subsection{Wood material}

2.1. Drvni materijal

Scotch pine (Pinus sylvestris L.) and Eastern beech (Fagus orientalis Lipsky) wood, which are widely used in the woodwork industry and decoration applications, were used as wood material. Wood materials, which have a moisture content of approximately $12 \%$, were selected randomly from a timber company in Düzce, Turkey. Wood specimens were cut in rough sizes from sapwood, in accordance with the study methodology. The air-dry density values of specimens were $534 \mathrm{~kg} / \mathrm{m}^{3}$ for pine and $698 \mathrm{~kg} / \mathrm{m}^{3}$ for beech. The surfaces of the specimens to be used in the color tests were sanded with 80 and 100 number sandpaper, respectively, using a caliber sanding machine. The specimens were cut to the dimensions of $40 \mathrm{~mm} \times 30 \mathrm{~mm} \times$ $5 \mathrm{~mm}(\mathrm{~L} \times \mathrm{R} \times \mathrm{T})$ for color tests and $40 \mathrm{~mm} \times 15 \mathrm{~mm}$ $\times 5 \mathrm{~mm}(\mathrm{~L} \times \mathrm{R} \times \mathrm{T})$ for fungal decay tests. The test specimens were prepared in a number sufficient to accommodate six repetitions $(n=6)$ for each variable in the study.

\subsection{Preparation of plant solutions}

2.2. Priprema biljnih otopina

Flowers of Rhododendron luteum and Rhododendron ponticum L. plants were used to test the coloring potential of wood and their protection against fungal rot. Both plant flowers were obtained in the season from Gürgentepe district of Ordu province in Turkey and dried in the shade for three months. Then the flowers were ground and powdered. The extraction of both plant flowers was carried out according to the hot water method under the conditions shown in Table 1.

At the end of the process, the extracts were separated from their solid parts by filtering with a filter paper. Pure water was added to the solution in the amount evaporated during boiling and was brought to the initially determined concentration ratios. Mordant substances were added to the solutions in order to ensure the adhesion of dyestuffs to wood samples and to obtain different color tones. Ferrous sulfate $\left(\mathrm{Fe}_{2}\left(\mathrm{SO}_{4}\right)_{3} \times 7 \mathrm{H}_{2} \mathrm{O}\right)$, copper sulfate $\left(\mathrm{CuSO}_{2} \times 5 \mathrm{H}_{2} \mathrm{O}\right)$ and aluminum sulfate $\left(\mathrm{KAl}_{2}\left(\mathrm{SO}_{4}\right)_{3} \times 18 \mathrm{H}_{2} \mathrm{O}\right)$ were used as mordant in the study. Addition rates of mordant materials into the solution by weight were $3 \%, 5 \%$ and $5 \%$, respectively. Each mordant substance was added separately to the plant extracts prepared in different concentrations.

\subsection{Impregnation}

2.3. Impregnacija

Before impregnation, wood specimens prepared for decay testing were dried at $60{ }^{\circ} \mathrm{C}$ for $48 \mathrm{~h}$ and weighed. The wood specimens were dried at a low temperature $\left(60{ }^{\circ} \mathrm{C}\right)$ in order to prevent the closure of the cell passages due to sudden drying and to ensure deep impregnation. A cylindrical tank assembly with a vacuum holder was used in the impregnation of the wood specimens. A pre-vacuum equivalent pressure of 760 $\mathrm{mm} / \mathrm{Hg}$ was applied to the specimens for 30 minutes and then the pressure of 8 bar was applied for $30 \mathrm{~min}$ (ASTM D 1413-99). The treated specimens were immediately removed and weighed to determine gross solution uptake. The retentions of wood specimens impregnated with plant solutions were determined using Eq. 1:

$$
\text { Retention }\left(\mathrm{kg} / \mathrm{m}^{3}\right)=(G \times C) / V \times 10
$$

Where $G$ is the amount $(\mathrm{g})$ of solution absorbed by the specimens, $C$ is the concentration of the solution, and $V$ is the volume $\left(\mathrm{cm}^{3}\right)$ of the wood specimens.

Classical immersion method, which is a more economical method, was used in the impregnation process of the color test specimens. The samples were completely immersed in a container filled with solution under atmospheric pressure and at $(20 \pm 2){ }^{\circ} \mathrm{C}$ temperature and kept for 2 hours. After the impregnation processes, all specimens remained in a conditioning cabin ( $\mathrm{RH} 65 \pm 3$ $\%$ and $20 \pm 2{ }^{\circ} \mathrm{C}$ ) until they reached a stable weight.

Table 1 Extraction conditions

Tablica 1. Uvjeti ekstrakcije

\begin{tabular}{|c|c|c|c|c|}
\hline \multirow{2}{*}{$\begin{array}{c}\text { Plant species } \\
\text { Vrsta biljke }\end{array}$} & $\begin{array}{c}\text { Concentration, \% } \\
\text { (plant/pure water) } \\
\text { Koncentracija, \% } \\
\text { (biljka/čista voda) }\end{array}$ & $\begin{array}{c}\text { Extraction method } \\
\text { Metoda ekstrakcije }\end{array}$ & $\begin{array}{c}\text { Temperature, }{ }^{\circ} \mathbf{C} \\
\text { Temperatura, }{ }^{\circ} \mathrm{C}\end{array}$ & $\begin{array}{c}\text { Duration, min } \\
\text { Trajanje, min }\end{array}$ \\
\cline { 2 - 5 } $\begin{array}{c}\text { R. luteum } \\
\text { or } \\
\text { R. ponticum }\end{array}$ & 2 & $\begin{array}{c}\text { Hot water (decoction) } \\
\text { vruća voda (dekocija) }\end{array}$ & 100 & 60 \\
\cline { 2 - 4 } & 7 & & \\
\hline
\end{tabular}




\subsection{Determination of decay resistance}

2.4. Određivanje otpornosti na propadanje

Decay test was carried out in the Wood Preservation Laboratory of Düzce University according to TS 5563 EN 113:1996. Impregnated and control specimens were then exposed to the white rot fungus Trametes versicolor (L: Fr.) Pilat. Test fungi were grown on a malt extract agar medium, which was autoclaved at $121^{\circ} \mathrm{C}$ for $20 \mathrm{~min}$ and poured into petri dishes $(15 \mathrm{ml}$ for each petri dish). The petri dishes were incubated at $(24 \pm 2)^{\circ} \mathrm{C}$ and $(75 \pm 2) \%$ relative humidity until the mycelium covered the whole of the agar surface. The wood specimens were dried at $60{ }^{\circ} \mathrm{C}$ for $48 \mathrm{~h}$, weighed $\left(M_{1}\right)$ to determine the initial weight before fungi exposure and then sterilized at $(121 \pm 2){ }^{\circ} \mathrm{C}$ for $20 \mathrm{~min}$. Control and treated specimens were placed in the petri dishes, with a feeder strip laid. Following fungal exposure of 12 weeks at $24{ }^{\circ} \mathrm{C}$ and $75 \%$ relative humidity, the wood specimens were cleaned, dried (at $60{ }^{\circ} \mathrm{C}$ for $48 \mathrm{~h}$ ), and weighed $\left(M_{2}\right)$. The mass losses were calculated using Eq. 2:

$$
\text { Mass loss }(\%)=\left(M_{1}-M_{2}\right) / M_{1} \times 100
$$

\subsection{Determination of color changes}

\subsection{Određivanje promjene boje}

Color measurements were performed according to ASTM D2244-16 using the BYK-Gardner Spectrophotometer instrument. The three-dimensional CIEL $* a * b *$ color system was used for measuring the color values of specimens. In this system, $L^{*}$ (lightness) is positioned on the black-white axis $\left(L^{*}=0\right.$ for black, $L^{*}=100$ for white), $a^{*}$ on the red-green axis (red for positive values and green for negative values), and $b^{*}$ on the yellow-blue axis (yellow for positive values and blue for negative values). $L^{*}, a^{*}$ and $b^{*}$ values of the wood specimens were analyzed separately. In addition, by using the differences $\left(\Delta L^{*}, \Delta a^{*}\right.$ and $\left.\Delta b^{*}\right)$ between the values of $L^{*}, a^{*}$ and $b^{*}$ values before and after the plant extract applications, the total color change $\left(\Delta E^{*}\right)$ in the specimens was determined according to Equation (3),

$$
\Delta E^{*}=\sqrt{\left(\Delta L^{*}\right)^{2}+\left(\Delta a^{*}\right)^{2}+\left(\Delta b^{*}\right)^{2}}
$$

Where $\Delta L^{*}$ is the difference in lightness $\left(L^{*}\right.$ $\left.-L_{\text {control }}^{*}\right), \Delta a^{*}$ is the difference in $a^{*}$ value $\left(a^{*}{ }_{\text {treated }}^{\text {treated }}-\right.$ $\left.a_{\text {control }}^{*}\right), \Delta b^{*}$ is the difference in $b^{*}$ value $\left(b_{\text {treated }}^{*}-\right.$ $b_{\text {control }}^{*}$. Measurements were taken from two different regions of each specimen and their averages were recorded as a single value.

\subsection{Statistical analyses}

\subsection{Statistička analiza}

Analysis of variance (ANOVA) tests were performed to determine the effect of plant solutions on the mass loss of pine and beech specimens exposed to $T$. versicolor at the 0.05 significance level. Significant differences between the average values of the groups were compared using Duncan's test.

\section{RESULTS AND DISCUSSION}

\section{REZULTATI I RASPRAVA}

\subsection{Retention}

3.1. Retencija

The retention values of pine and beech specimens impregnated with plant solutions at different concentration levels are given in Table 2. Higher retention values were found in $R$. luteum solutions compared to $R$. ponticum solutions for both wood species. In addition, retention values increased due to the increase in concentration of the solutions.

\subsection{Decay resistance}

3.2. Otpornost na propadanje

The mass loss values of wood specimens treated with $R$. luteum and $R$. ponticum extracts were similar. The effect of plant species on mass loss in both wood species was statistically insignificant (Table 3). Additionally, the mass loss from $T$. versicolor was higher in beech specimens than in pine specimens. Bozkurt et al. (1993) stated that white rot fungus has a greater effect on hardwood species compared to softwood species. In ad-

Table 2 Retention values

\begin{tabular}{|c|c|c|c|c|c|}
\hline \multirow{3}{*}{$\begin{array}{c}\text { Concentration, \% } \\
\text { Koncentracija, \% }\end{array}$} & \multirow{3}{*}{$\begin{array}{c}\text { Mordant substance } \\
\text { Fiksator }\end{array}$} & \multicolumn{4}{|c|}{ Retention / Retencija, $\mathrm{kg} / \mathrm{m}^{3}$} \\
\hline & & \multicolumn{2}{|c|}{ Pine / Borovina } & \multicolumn{2}{|c|}{ Beech / Bukovina } \\
\hline & & R. luteum & R. ponticum & R. luteum & R. ponticum \\
\hline \multirow{4}{*}{2} & Non-mordant / bez fiksatora & $10.5(1.0)$ & $8.6(1.0)$ & $11.4(0.4)$ & $10.1(0.3)$ \\
\hline & Ferrous sulfate / željezov sulfat & $10.4(0.6)$ & $10.5(0.9)$ & $10.2(2.2)$ & $8.6(2.4)$ \\
\hline & Copper sulfate / bakrov sulfat & $10.0(0.7)$ & $9.8(0.4)$ & $9.9(0.4)$ & $9.6(0.4)$ \\
\hline & Aluminum sulfate / aluminijev sulfat & $9.5(1.2)$ & $8.5(0.8)$ & $9.1(0.5)$ & $8.7(0.4)$ \\
\hline \multirow{4}{*}{4} & Non-mordant / bez fiksatora & $21.3(2.2)$ & $17.3(1.3)$ & $22.2(0.4)$ & $20.5(0.5)$ \\
\hline & Ferrous sulfate / željezov sulfat & $21.2(0.9)$ & $20.6(0.7)$ & $20.4(0.5)$ & $20.4(0.7)$ \\
\hline & Copper sulfate / bakrov sulfat & $19.2(2.1)$ & $19.9(1.1)$ & $19.9(0.8)$ & $20.2(0.5)$ \\
\hline & Aluminum sulfate / aluminijev sulfat & $17.5(1.8)$ & $18.2(1.5)$ & $17.8(1.4)$ & $18.2(0.8)$ \\
\hline \multirow{4}{*}{7} & Non-mordant / bez fiksatora & $37.5(1.9)$ & $34.9(2.7)$ & $38.2(0.5)$ & $36.9(1.0)$ \\
\hline & Ferrous sulfate / željezov sulfat & $37.0(2.5)$ & $34.9(2.6)$ & $36.4(0.8)$ & $34.6(2.2)$ \\
\hline & Copper sulfate / bakrov sulfat & $33.2(2.7)$ & $34.1(3.5)$ & $34.9(0.9)$ & $34.8(1.3)$ \\
\hline & Aluminum sulfate / aluminijev sulfat & $35.6(4.4)$ & $32.9(2.8)$ & $34.8(0.6)$ & $31.4(2.3)$ \\
\hline
\end{tabular}

Tablica 2. Vrijednosti retencije 
........Pelit, Alkan, Yalcin: Decay Resistance and Color Change of Pine and Beech Wood...

Table 3 Duncan's one-way test results for mass losses in pine and beech specimens

Tablica 3. Rezultati Duncanova jednosmjernog testa za gubitak mase uzoraka borovine i bukovine

\begin{tabular}{|l|c|c|c|c|}
\hline \multirow{2}{*}{ Factor / Čimbenik } & \multicolumn{3}{|c|}{ Mass loss / Gubitak mase, \% } \\
\cline { 2 - 5 } & \multicolumn{2}{|c|}{ Pine / Borovina } & \multicolumn{2}{c|}{ Beech / Bukovina } \\
\cline { 2 - 5 } & Mean & SG & Mean & SG \\
\hline Plant species / Vrsta biljke & & & & $\mathrm{a}$ \\
\hline R. luteum & 9.44 & $\mathrm{a}$ & 16.75 & $\mathrm{a}$ \\
\hline R. ponticum & 9.06 & $\mathrm{a}$ & 16.73 & $\mathrm{a}$ \\
\hline Concentration / Koncentracija & & & & $\mathrm{a}$ \\
\hline $2 \%$ & 9.64 & $\mathrm{a}$ & 16.96 & $\mathrm{a}$ \\
\hline $4 \%$ & 9.50 & $\mathrm{a}$ & 16.61 & \\
\hline $7 \%$ & 8.62 & $\mathrm{~b}$ & 16.65 & $\mathrm{a}$ \\
\hline Mordant substance / Fiksator & & & & $\mathrm{b}$ \\
\hline Control (untreated) / kontrolni uzorci (netretirani) & 21.35 & $\mathrm{a}$ & 39.87 & $\mathrm{~d}$ \\
\hline Non-mordant / bez fiksatora & 18.58 & $\mathrm{~b}$ & 37.55 & $\mathrm{c}$ \\
\hline Ferrous sulfate / željezov sulfat & 1.27 & $\mathrm{~d}$ & 1.29 & $\mathrm{c}$ \\
\hline Copper sulfate / bakrov sulfat & 2.36 & $\mathrm{c}$ & 2.55 & $\mathrm{c}$ \\
\hline Aluminum sulfate / aluminijev sulfat & 2.71 & $\mathrm{c}$ & 2.42 & $\mathrm{c}$ \\
\hline
\end{tabular}

SG: Statistical group (different letters denote a significant difference) / statistička grupa (različita slova označavaju značajnu razliku)

dition, the decay resistance varies between wood species and within the same species, depending on the tree age, growing region conditions and seasonal differences. It was also found in different study results that mass loss due to T. versicolor (white rot fungus) was higher in beech wood than in pine wood (Goktas et al., 2008; Yalcin, 2012; Ozen et al., 2014; Colak, 2016).

For pine specimens, the highest mass loss regarding concentration level was found at $2 \%$ concentration and the lowest was determined at $7 \%$ concentration. However, the effect of the concentration level on the mass loss of beech specimens was insignificant (Table 3 ). Mass loss tended to decrease with increasing concentration level in specimens treated with non-mordant extracts. However, the effect of the concentration level on wood specimens treated with all mordant added extracts is not clear (Figure 1).

The highest mass loss regarding mordant substance was found to be in the control (untreated) speci- mens $(21.35 \%$ for pine and $39.87 \%$ for beech), while the lowest was obtained in the specimens treated with ferrous sulfate-added extracts $(1.27 \%$ for pine and $1.29 \%$ for beech) (Table 3 ). Mass losses were slightly reduced in specimens impregnated with non-mordant extracts compared to control (untreated) specimens. However, mass loss was significantly reduced in all specimens impregnated with mordant-added extracts. Mordant substances were found to be the main influencing factor on the mass loss of specimens exposed to T. versicolor (Figure 1). The mass loss results of specimens treated with copper sulfate and aluminum sulfate-added extracts were similar and the difference between them was statistically insignificant. The most successful results for both wood species were determined in specimens treated with ferrous sulfate-added extracts. For pine wood, the mass loss in the specimens impregnated with non-mordant, ferrous sulfate, copper sulfate and aluminum sulfate-added extracts decreased

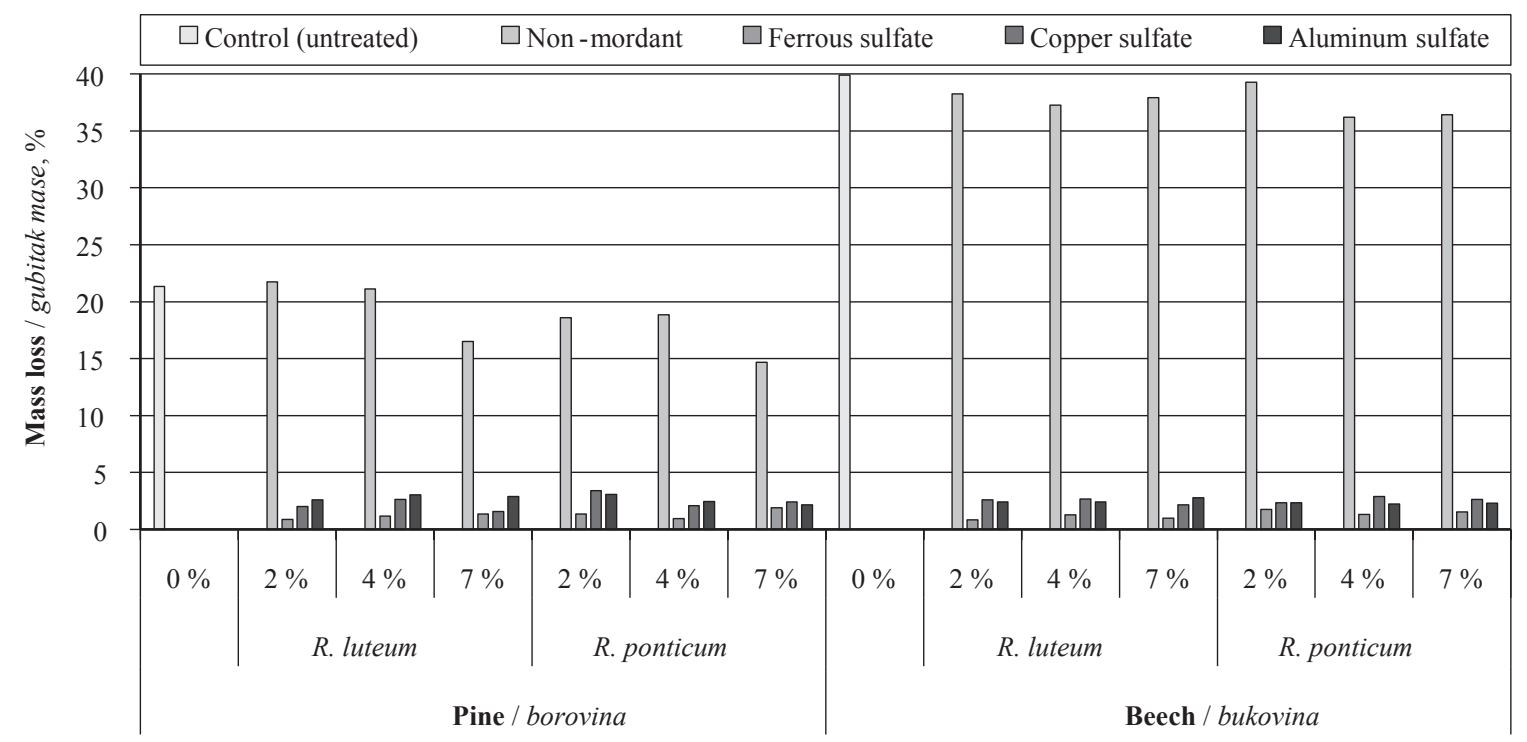

Figure 1 Mass losses for pine and beech wood exposed to T. versicolor depending on plant solutions

Slika 1. Gubitci mase uzoraka borovine i bukovine izloženih $T$. versicolor ovisno o biljnim otopinama 
$13 \%, 94 \%, 89 \%$ and $87 \%$, respectively. For beech wood under the same conditions, the mass loss decreased $6 \%, 97 \%, 94 \%$ and $94 \%$, respectively. It is known that ferrous, aluminum and especially copper compounds are used in some biocides and these compounds are good fungicides. In a previous study, it was stated that the resistance against brown and white rot fungus in wood materials treated with ferrous sulphate, aluminum sulphate, and copper sulphate mixed madder root extracts was much higher than that of untreated or synthetic dye treated wood materials. In addition, it was reported that mordant agents have the ability to make a complex chemical bond with wood components having -OH groups, which may have an effect on fungal resistance (Ozen et al., 2014). Yamaguchi (2001) determined that chemically modified mimosa tannins and copper are effective against brown and white rot fungi that cause rot in wood material. Shah et al., (2010) stated that the production of lignocellulose degrading enzymes decreased by iron and copper aggregated nanoparticles in the fungus $T$. versicolor. Nano-copper preservatives are able to deliver bioactive components into wood cell walls and thus improve leach resistance as well as bio-durability (Matsunaga et al., 2009). Furthermore, it has been reported by previous studies that treatment with nano-copper significantly improved decay resistance to $T$. versicolor (Kartal et al., 2009; Akhtari and Arefkhani, 2013; Pařil et al., 2017). Moreover, due to the combined effect of natural tannins and metal mordant (copper sulfate) bonding, resistance to microorganisms in cotton and silk fabrics has increased significantly and the rate of fading has been greatly reduced with this eco-friendly process (Prabhu et al., 2011).

\subsection{Color change}

\subsection{Promjena boje}

The average $L^{*}, a^{*}$ and $b^{*}$ values of pine and beech specimens impregnated with $R$. luteum and $R$. ponticum extracts prepared in different concentrations are given in Table 4 . The $L^{*}$ value of wood specimens impregnated with $R$. luteum extracts was generally higher than that of $R$. ponticum. It can be said that the original colors of the plant flowers used in the study affected the results, because $R$. ponticum flowers have a purplish pink color, while $R$. luteum flowers have a lighter golden yellow color (Stevens, 1978; Kucuk, 2005; Ceter and Guney, 2011).

After treatment with all extracts, the $L^{*}$ value of pine and beech specimens decreased (Table 4) and the samples darkened to a certain extent (Figure 2 and 3). A decrease in the $L^{*}$ value indicates a darker color tone, and an increase indicates a lighter color (Sogutlu and Sonmez, 2006). For both wood species, the $L^{*}$ value was similar for specimens treated with non-mordant, copper sulfate and aluminum sulfate-added extracts. The lowest $L^{*}$ values were determined in specimens treated with ferrous sulfate-added extracts. The $L^{*}$ value of these specimens decreased by an average of $27 \%$ in pine and $22 \%$ in beech compared to the control (untreated) specimens. In previous studies us- ing madder root (Goktas et al., 2009), acorn (Peker et al., 2012) and red beetroot (Yeniocak et al., 2015) extracts, the lowest $L^{*}$ values for pine and beech wood were determined in ferrous sulfate mixed solutions compared to other mordant mixed solutions. Furthermore, wooden materials colored with all metal mordant mixed solutions have darker colors (Yeniocak et al., 2015). Prabhu and Bhute (2012) stated that aluminum sulfate, potassium dichromate and tin (Stannous chloride) falls under the category of brightening mordants, while copper sulphate and ferrous sulphates are dulling mordants. Ferrous sulfate mordant causes significant color differences as well as a color shift towards dark tones, while aluminum sulphate mordant increases the lightness value of the color but slightly affects the color tone (Acar, 2013).

The $L^{*}$ value of the impregnated specimens tends to decrease due to the increase in the concentration level of the solutions (Table 4). It can be said that with the increase in concentration, the increase in the ratio of extractives in darker hues compared to the natural color of wood materials has an effect on the results.

The highest $a^{*}$ values for both wood species were determined in specimens (except pine specimens treated with ferrous sulfate-added extracts) impregnated with $R$. ponticum solutions. In a previous study, an Anthocyanidin named Peonidin causing purple-red coloration in the flowers of the $R$. ponticum plant was determined (Gündüz, 1996). The increase in the concentration level of the solutions caused a general increase in the $a^{*}$ value of pine specimens. This situation is more pronounced in specimens treated with $R$. ponticum solutions. However, $a^{*}$ values decreased because of increasing concentration in pine specimens treated with ferrous sulfate-added both plant solutions. On the other hand, the effect of the concentration level was not evident for beech specimens (Table 4). After treatment with extracts, the $a^{*}$ value of pine and beech specimens differed depending on the mordant substance. For pine wood, in specimens treated with non-mordant and aluminum sulfate-added extracts, the $a^{*}$ value increased by an average of $55 \%$ and $61 \%$, respectively, and consequently the red color tendency of the specimens also increased. On the other hand, in specimens treated with ferrous sulfate and copper sulfate-added extracts, the $a^{*}$ value decreased by an average of $55 \%$ and $56 \%$, respectively, and consequently the green color tendency of the specimens increased (Table 4 and Figure 2). For beech wood, the $a^{*}$ value of specimens treated with non-mordant extracts gave similar results to control (untreated) specimens. The $a^{*}$ value increased by an average of $8 \%$ in specimens treated with aluminum sulfate-added extracts. It was reduced by $18 \%$ in specimens treated with copper sulfate-added extracts. However, the most significant change in $a^{*}$ value of beech specimens was observed after treatment with ferrous sulfate-added extracts. In these specimens, the $a^{*}$ value decreased by $76 \%$ compared to the control (untreated) specimens and the green color tendency increased significantly (Table 4 and Figure 3). In the literature, it has been stated that ferrous sulphate mordant 
........ Pelit, Alkan, Yalcin: Decay Resistance and Color Change of Pine and Beech Wood...

Table 4 Color values in pine and beech wood impregnated with plant solutions

Tablica 4. Vrijednosti boje uzoraka borovine i bukovine impregniranih biljnim otopinama

\begin{tabular}{|c|c|c|c|c|c|c|c|c|}
\hline \multirow{3}{*}{$\begin{array}{c}\text { Plant } \\
\text { species } \\
\text { Vrsta biljke }\end{array}$} & \multirow{3}{*}{$\begin{array}{c}\text { Concentration, \% } \\
\text { Koncentracija, \% }\end{array}$} & \multirow{3}{*}{$\begin{array}{c}\text { Mordant } \\
\text { substance } \\
\text { Fiksator }\end{array}$} & \multicolumn{6}{|c|}{ Color parameters / Parametri boje } \\
\hline & & & \multicolumn{3}{|c|}{ Pine / Borovina } & \multicolumn{3}{|c|}{ Beech / Bukovina } \\
\hline & & & $L^{*}$ & $a^{*}$ & $b^{*}$ & $L^{*}$ & $a^{*}$ & $b^{*}$ \\
\hline \multirow{12}{*}{ R. luteum } & \multirow{4}{*}{2} & $\begin{array}{l}\text { Non-mordant } \\
\text { bez fiksatora }\end{array}$ & $76.6(0.1)$ & $7.2(0.2)$ & $29.8(0.6)$ & $65.8(0.8)$ & $11.1(0.3)$ & $23.6(0.5)$ \\
\hline & & $\begin{array}{l}\text { Ferrous sulfate } \\
\text { željezov sulfat }\end{array}$ & $63.4(0.7)$ & $5.0(0.6)$ & $24.5(1.0)$ & $54.2(2.0)$ & $2.6(0.3)$ & $14.1(0.7)$ \\
\hline & & \begin{tabular}{|l|} 
Copper sulfate \\
bakrov sulfat
\end{tabular} & $73.9(1.3)$ & $0.5(0.2)$ & $26.9(0.4)$ & $65.0(1.2)$ & $9.4(0.3)$ & $23.2(0.6)$ \\
\hline & & $\begin{array}{l}\text { Aluminum sulfate } \\
\text { aluminijev sulfat }\end{array}$ & $77.1(0.9)$ & $7.9(0.3)$ & $32.4(0.8)$ & $66.0(0.3)$ & $12.3(0.4)$ & $25.5(0.4)$ \\
\hline & \multirow{4}{*}{4} & \begin{tabular}{|l|} 
Non-mordant \\
bez fiksatora
\end{tabular} & $75.9(1.2)$ & $7.3(0.4)$ & $29.5(0.6)$ & $65.1(1.1)$ & $11.0(0.5)$ & $23.0(0.6)$ \\
\hline & & \begin{tabular}{|l|} 
Ferrous sulfate \\
željezov sulfat \\
\end{tabular} & $62.1(1.1)$ & $3.8(0.9)$ & $22.9(0.8)$ & $53.5(1.4)$ & $2.7(0.3)$ & $14.2(0.8)$ \\
\hline & & $\begin{array}{l}\text { Copper sulfate } \\
\text { bakrov sulfat }\end{array}$ & $74.0(1.4)$ & $2.0(0.4)$ & $29.6(0.5)$ & $63.9(0.4)$ & $9.4(0.4)$ & $24.6(0.9)$ \\
\hline & & $\begin{array}{l}\text { Aluminum sulfate } \\
\text { aluminijev sulfat }\end{array}$ & $75.9(1.4)$ & $8.1(0.5)$ & $33.1(0.7)$ & $64.7(0.5)$ & $12.0(0.6)$ & $26.0(0.5)$ \\
\hline & \multirow{4}{*}{7} & $\begin{array}{l}\text { Non-mordant } \\
\text { bez fiksatora }\end{array}$ & $71.2(1.1)$ & $9.5(0.6)$ & $31.4(0.8)$ & $64.4(1.2)$ & $11.5(0.3)$ & $24.2(0.5)$ \\
\hline & & \begin{tabular}{|l|} 
Ferrous sulfate \\
željezov sulfat \\
\end{tabular} & $58.1(1.7)$ & $2.6(0.7)$ & $20.3(1.6)$ & $51.8(0.7)$ & $2.4(0.3)$ & $14.7(0.5)$ \\
\hline & & \begin{tabular}{|l} 
Copper sulfate \\
bakrov sulfat
\end{tabular} & $73.5(0.7)$ & $1.7(1.1)$ & $31.0(1.0)$ & $64.1(0.7)$ & $9.7(0.3)$ & $25.4(0.9)$ \\
\hline & & $\begin{array}{l}\text { Aluminum sulfate } \\
\text { aluminijev sulfat }\end{array}$ & $75.3(1.0)$ & $7.5(0.5)$ & $35.0(0.5)$ & $66.0(0.7)$ & $11.5(0.4)$ & $26.9(0.4)$ \\
\hline \multirow{12}{*}{ R. ponticum } & \multirow{4}{*}{2} & $\begin{array}{l}\text { Non-mordant } \\
\text { bez fiksatora }\end{array}$ & $67.8(1.1)$ & $8.9(0.6)$ & $27.9(1.3)$ & $63.3(0.5)$ & $12.1(0.7)$ & $24.0(0.2)$ \\
\hline & & $\begin{array}{l}\text { Ferrous sulfate } \\
\text { željezov sulfat }\end{array}$ & $62.1(1.2)$ & $2.6(0.3)$ & $19.8(0.6)$ & $55.7(1.5)$ & $3.5(0.3)$ & $14.6(0.6)$ \\
\hline & & $\begin{array}{l}\text { Copper sulfate } \\
\text { bakrov sulfat }\end{array}$ & $73.9(1.3)$ & $1.7(0.9)$ & $33.2(1.7)$ & $63.6(0.8)$ & $9.7(0.5)$ & $27.2(1.0)$ \\
\hline & & $\begin{array}{l}\text { Aluminum sulfate } \\
\text { aluminijev sulfat }\end{array}$ & $74.5(1.3)$ & $9.0(0.8)$ & $30.7(0.9)$ & $65.4(0.4)$ & $12.7(0.2)$ & $25.2(0.3)$ \\
\hline & \multirow{4}{*}{4} & $\begin{array}{l}\text { Non-mordant } \\
\text { bez fiksatora }\end{array}$ & $66.1(1.8)$ & $9.0(0.6)$ & $27.0(1.3)$ & $61.7(0.7)$ & $11.7(0.5)$ & $23.7(0.9)$ \\
\hline & & \begin{tabular}{|l} 
Ferrous sulfate \\
željezov sulfat
\end{tabular} & $58.6(1.1)$ & $1.1(0.4)$ & $17.7(0.6)$ & $54.7(1.2)$ & $3.0(0.3)$ & $14.7(0.3)$ \\
\hline & & $\begin{array}{l}\text { Copper sulfate } \\
\text { bakrov sulfat }\end{array}$ & $70.4(1.2)$ & $3.4(0.8)$ & $38.7(0.5)$ & $63.1(0.6)$ & $9.7(0.6)$ & $29.6(0.6)$ \\
\hline & & $\begin{array}{l}\text { Aluminum sulfate } \\
\text { aluminijev sulfat }\end{array}$ & $72.4(1.1)$ & $10.6(0.5)$ & $32.9(0.3)$ & $62.6(0.8)$ & $13.5(0.3)$ & $26.5(0.7)$ \\
\hline & \multirow{4}{*}{7} & $\begin{array}{l}\text { Non-mordant } \\
\text { bez fiksatora }\end{array}$ & $65.9(1.7)$ & $10.7(1.2)$ & $30.3(1.5)$ & $61.2(1.0)$ & $12.6(0.3)$ & $25.3(0.6)$ \\
\hline & & $\begin{array}{l}\text { Ferrous sulfate } \\
\text { željezov sulfat }\end{array}$ & $55.2(1.7)$ & $0.3(0.4)$ & $15.8(1.0)$ & $53.3(1.0)$ & $2.8(0.2)$ & $14.1(0.5)$ \\
\hline & & \begin{tabular}{|l|} 
Copper sulfate \\
bakrov sulfat \\
\end{tabular} & $67.8(1.1)$ & $5.7(0.8)$ & $40.9(1.1)$ & $61.8(0.9)$ & $9.7(0.5)$ & $32.1(0.9)$ \\
\hline & & $\begin{array}{l}\text { Aluminum sulfate } \\
\text { aluminijev sulfat }\end{array}$ & $68.9(1.3)$ & $11.4(1.0)$ & $33.6(0.9)$ & $61.8(0.6)$ & $13.7(0.3)$ & $27.8(0.6)$ \\
\hline \multicolumn{3}{|c|}{ Control / Kontrolni uzorci } & $82.0(0.1)$ & $5.6(0.1)$ & $26.3(0.1)$ & $69.5(0.1)$ & $11.7(0.1)$ & $21.5(0.1)$ \\
\hline
\end{tabular}

Values in parentheses are standard deviations. / Vrijednosti u zagradama standardne su devijacije.

is used to obtain dark colors and black colors with all dyestuffs, while copper sulphate mordant gives browngreen color with many dyestuffs and gives uninteresting dark colors with some dyestuffs and is used to obtain green colors as mordant (Anonymous, 1991).

The $b^{*}$ value of pine and beech specimens increased after treatment with all other solutions except ferrous sulfate-added solutions. For pine wood, the $b^{*}$ value was higher in $R$. luteum compared to $R$. ponticum for non-mordant and ferrous sulfate-added solutions. However, higher $b^{*}$ values were obtained in $R$. ponticum compared with $R$. luteum for copper sulfate and aluminum sulfate-added solutions. For beech wood, the $b^{*}$ value of specimens treated with $R$. luteum and $R$. 
Pelit, Alkan, Yalcin: Decay Resistance and Color Change of Pine and Beech Wood... ........

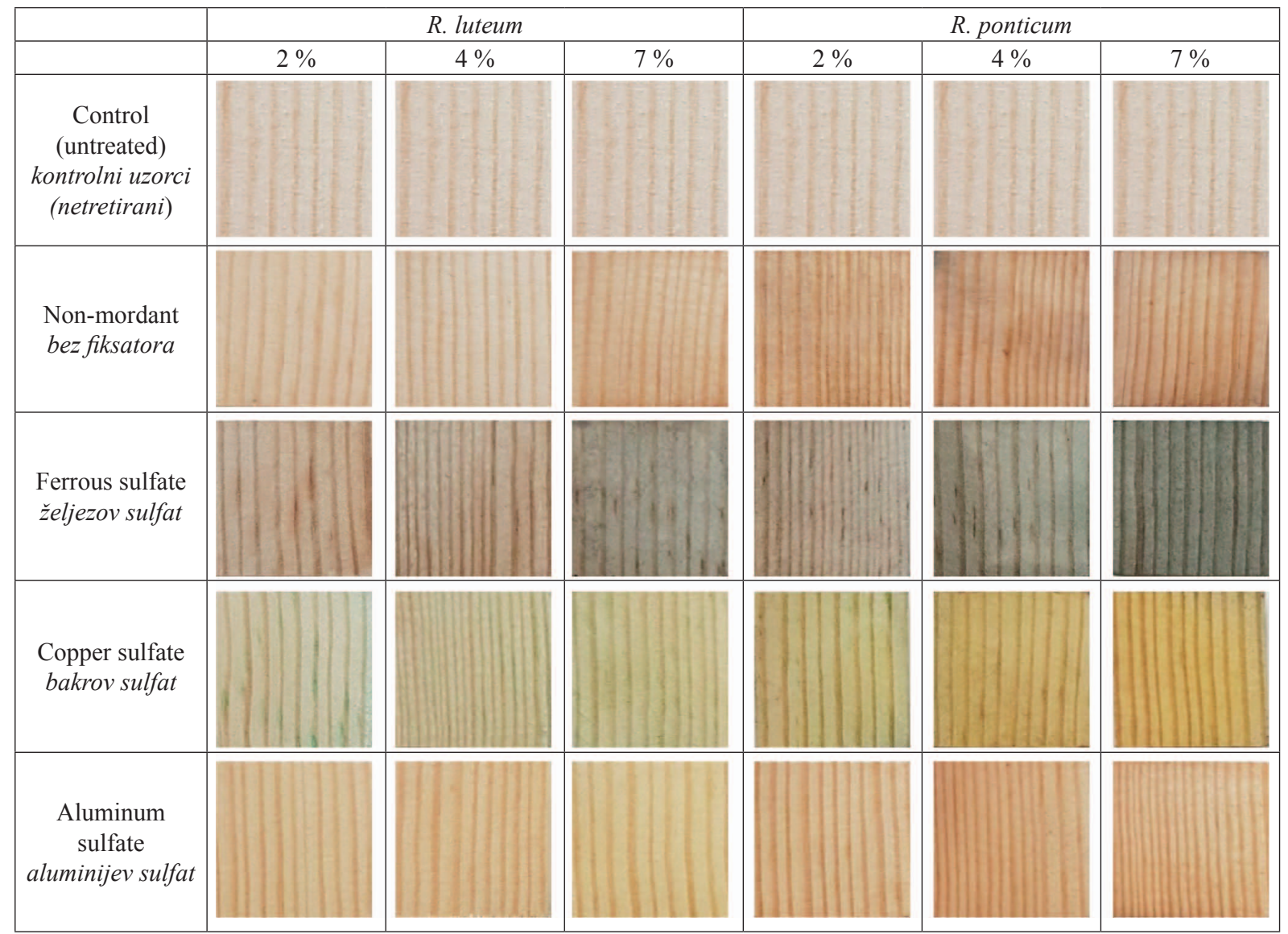

Figure 2 Color change images in pine wood after impregnation with plant solutions

Slika 2. Promjena boje borovine nakon impregnacije biljnom otopinom

\begin{tabular}{|c|c|c|c|c|c|c|}
\hline & \multicolumn{3}{|c|}{ R. luteum } & \multicolumn{3}{|c|}{ R. ponticum } \\
\hline & $2 \%$ & $4 \%$ & $2 \%$ & $4 \%$ & $2 \%$ & $4 \%$ \\
\hline $\begin{array}{c}\text { Control } \\
\text { (untreated) } \\
\text { kontrolni } \\
\text { uzorci } \\
\text { (netretirani) }\end{array}$ & & & & & & \\
\hline $\begin{array}{l}\text { Non-mordant } \\
\text { bez fiksatora }\end{array}$ & & 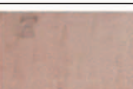 & 4 & 4 & & \\
\hline $\begin{array}{l}\text { Ferrous sulfate } \\
\text { željezov sulfat }\end{array}$ & & & & $\sqrt{14}$ & & \\
\hline $\begin{array}{l}\text { Copper sulfate } \\
\text { bakrov sulfat }\end{array}$ & & 4 & 4 & 4 & & \\
\hline $\begin{array}{l}\text { Aluminum } \\
\text { sulfate } \\
\text { aluminijev } \\
\text { sulfat }\end{array}$ & & 4 & 4 & 4 & 3 & 4 \\
\hline
\end{tabular}

Figure 3 Color change images in beech wood after impregnation with plant solutions

Slika 3. Promjena boje bukovine nakon impregnacije biljnom otopinom 


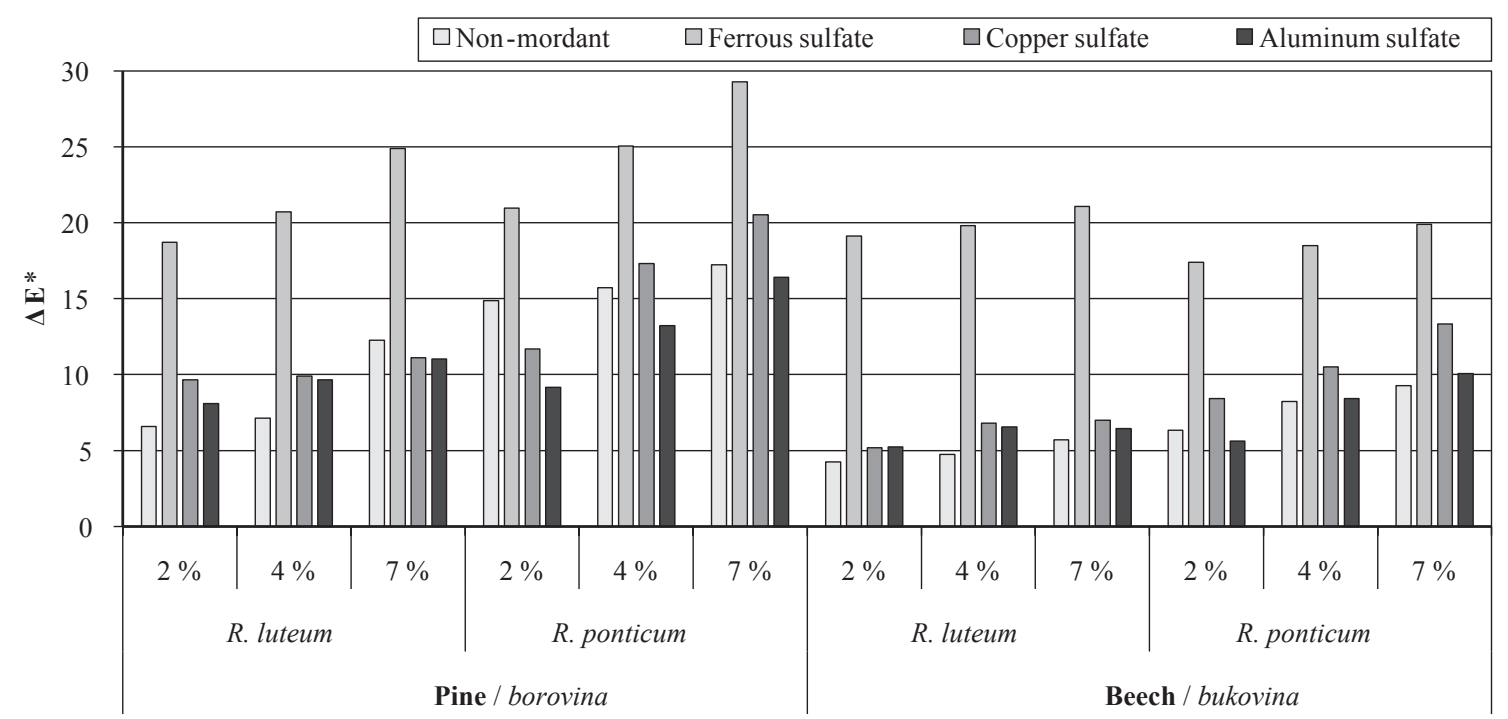

Figure 4 Total color change $\left(\Delta E^{*}\right)$ for impregnated pine and beech wood according to control (untreated) samples Slika 4. Ukupna promjena boje $\left(\Delta E^{*}\right)$ impregniranih uzoraka borovine i bukovine u usporedbi s kontrolnim (netretiranim) uzorcima

ponticum solutions (except for copper sulfate-added solutions) was similar. Higher $b^{*}$ values were determined in $R$. ponticum for copper sulfate-added solutions. The $b^{*}$ value of pine and beech specimens (except specimens treated with ferrous sulfate-added extracts) increased due to the increase in the concentration ratio of the solutions. For pine specimens treated with ferrous sulfate-added extracts, the $b^{*}$ value decreased with increasing concentration ratio, while for beech specimens the effect of concentration ratio was insignificant (Table 4). The $b^{*}$ value of pine specimens treated with non-mordant, copper sulfate and aluminum sulfate-added extracts increased by $3 \%, 17 \%$ and $16 \%$, respectively, compared to the control (untreated) specimens. Whereas, the $b^{*}$ value of beech specimens increased by $6 \%, 18 \%$ and $15 \%$, respectively. Especially after treatment with copper sulfate and aluminum sulfate-added extracts, the yellow color tendency of the specimens increased. On the other hand, the $b^{*}$ value of pine and beech specimens treated with ferrous sulfate-added extracts decreased on average by $25 \%$ and $35 \%$, respectively, compared to the control specimens. In these specimens, the blue color tendency was increased (Figure 2 and 3).

After treatment with $R$. luteum and $R$. ponticum extracts, the total color change $\left(\Delta E^{*}\right)$ is higher in pine wood than in beech wood. It can be said that the natural color of pine wood, being more light than beech wood, has an effect on the results. Yeniocak et al., (2017) stated that different interactions of natural extracts and mordant-added extracts with wood species and differences in the chemical composition of wood species may be effective in color change. On the other hand, genetic, environmental and technical factors such as anatomical structure, extractive substance content, heat, light, moisture, alkalis, acids, steaming, drying and finishing affect the color change of wood (Temiz et al., 2005; Peker et al., 2012; Bekhta et al., 2014; Pelit, 2017). Regarding the plant species, the $\Delta E^{*}$ was higher in specimens treated with $R$. ponticum solutions com- pared to R. luteum. However, as an exception, the $\Delta E^{*}$ was found to be higher in beech specimens treated with ferrous sulfate-added $R$. luteum solutions. Due to the increase in the concentration level of the solutions, the $\Delta E^{*}$ value increased in all impregnated wood specimens (Figure 4). The $\Delta E^{*}$ value in pine specimens treated with $R$. luteum and $R$. ponticum solutions prepared at $7 \%$ concentration increased by $38 \%$ and 47 $\%$, respectively, compared to $2 \%$ concentration. For beech specimens under the same conditions, the $\Delta E^{*}$ increased by $19 \%$ and $39 \%$, respectively. Regarding the mordant substance, the highest $\Delta E^{*}$ values for all solutions were determined in specimens impregnated with ferrous sulfate-added extracts. Compared to the specimens impregnated with other mordant added extracts, the $\Delta E^{*}$ value was significantly higher in these specimens. The decrease in $a^{*}$ values of these specimens considerably affected the results. Although the $\Delta E^{*}$ values of the specimens treated with non-mordant, copper sulfate and aluminum sulfate-added extracts differ depending on the plant species and concentration level, the $\Delta E^{*}$ values in these specimens were generally found to be close to each other (Figure 4).

\section{CONCLUSIONS 4. ZAKLJUČAK}

Mass losses in wood specimens exposed to white rot fungus after treatment with $R$. luteum and $R$. ponticum plant extracts were similar, and the effect of plant species on mass losses was insignificant. The mass loss of the specimens impregnated with nonmordant plant extracts was slightly reduced compared to the control (untreated) specimens. However, mass losses were significantly reduced in pine and beech specimens impregnated with mordant added extracts. While similar results were obtained for specimens treated with copper sulfate and aluminum sulfateadded extracts, the most successful results were determined in specimens treated with ferrous sulfate- 
added extracts. After impregnation, the mass loss of pine and beech specimens decreased up to $94 \%$ and $97 \%$, respectively. In addition, mass losses tend to decrease with increasing concentration level in nonmordant extracts. However, the effect of the concentration level was not pronounced in mordant-added extracts. Mordant substances were the main factor influencing the mass loss of wood specimens.

The $L^{*}, a^{*}$ and $b^{*}$ color values of the impregnated pine and beech specimens varied depending on the plant species, concentration level and mordant substances. After treatment with plant extracts, the $L^{*}$ value of all specimens (especially those treated with ferrous sulfate-added extracts) decreased and the specimens darkened. In wood specimens (especially pine) treated with non-mordant and aluminum sulfate-added extracts, the $a^{*}$ and $b^{*}$ values increased due to the increase in the concentration level and the red-yellow color tendency of these specimens also increased. In wood specimens treated with copper sulfate-added extracts, the $a^{*}$ value decreased and the $b^{*}$ value increased. Depending on this situation, the green-yellow color tendency of these specimens increased. In specimens treated with ferrous sulfate-added extracts, both $a^{*}$ and $b^{*}$ values decreased due to the increase in the concentration level and the green-blue color tendency of these specimens increased. Total color change $\left(\Delta E^{*}\right)$ is higher in pine as wood type, $R$. ponticum as plant species, $7 \%$ as concentration level and ferrous sulfate as mordant substance.

As a result, $R$. luteum and $R$. ponticum extracts did not have sufficient resistance to $T$. versicolor fungus. Therefore, it can be recommended to use natural extracts in combination with mordant substances to significantly improve the decay resistance and increase the color options.

\section{REFERENCES}

5. LITERATURA

1. Acar, G., 2013: Developing of Natural Dyed Fabric Friendly with Natura and Human Health. Master Thesis, Erciyes University, Kayseri, Turkey.

2. Akgun, M., 2019: Determination of Antimicrobial, Antioxidant and Bioactive Properties of Honeys from Different Rhododendron Species. Master Thesis, Ordu University, Turkey.

3. Akhtari, M.; Arefkhani, M., 2013: Study of microscopy properties of wood impregnated with nanoparticles during exposed to white-rot fungus. Agriculture Science Developments, 2 (11): 116-119.

4. Bekhta, P.; Proszyk, S.; Krystofiak, T., 2014: Colour in short-term thermo-mechanically densified veneer of various wood species. European Journal of Wood and Wood Products, 72 (6): 785-797. https://doi.org/10.1007/s00107-014-0837-1.

5. Birinci, E.; Tutus, A.; Cicekler, M., 2020: Evaluation of Rhododendron Luteum and Rhododendron Ponticum in Pulp and Paper Production. Drvna industrija, 71 (4): 365 370. https://doi.org/10.5552/drvind.2020.1943.

6. Broda, M., 2020: Natural compounds for wood protection against fungi - A Review. Molecules, 25 (15): 3538. https://doi.org/10.3390/molecules25153538.
7. Bozkurt, A. Y.; Goker, Y.; Erdin, N., 1993: Impregnation technique. Istanbul University, Istanbul (in Turkish).

8. Ceter, T.; Guney, K., 2011: Rhododendron and mad honey. Uludag Bee Journal, 11 (4): 124-129. https://dergipark.org.tr/tr/pub/uluaricilik/issue/52028/162332 (Accessed Oct. 01, 2020).

9. Colak, M., 2016: Determination of antifungal and antibacterial activities of natural dye of Pomegranate skin (Punica granatum L.) implemented on wooden materials. Wood Research, 61 (5): 709-717.

10. Goktas, O.; Baysal, E.; Ozen, E.; Mammadov, R.; Duru, M. E., 2008: Decay resistance and color stability of wood treated with Juglans regia extract. Wood Research, 53 (3): 27-36.

11. Goktas, O.; Ozen, E.; Baysal, E.; Mammadov, R.; Alma, H.; Sonmez, A., 2009: Color stability of wood treated with madder root (Rubia tinctorium L.) extract after lightfastness test. Wood Research, 54 (1): 37-44.

12. Goktas, O.; Ozen, E.; Baysal, E.; Mammadov, R.; Alma, M. H., 2010: A research on the usage of extracts from two poisonous plants (Muscari neglectum Guss. and Gynandriris sisyrinchium (L.) Parl.) as a wood preservative. Wood Research, 55 (2): 53-62.

13. Gündüz, G., 1996: The Extraction of (Rhododendron ponticum L.) Flowers and Determination as an Coloring Matter. Master Thesis, Zonguldak Karaelmas University, Zonguldak, Turkey.

14. Kartal, S. N.; Green F., III.; Clausen, C. A., 2009: Do the unique properties of nanometals affect leachability or efficacy against fungi and termites? International Biodeterioration \& Biodegradation, 63 (4): 490-495. https://doi.org/10.1016/j.ibiod.2009.01.007.

15. Kartal, S. N.; Hwang, W. J.; Imamura, Y.; Sekine, Y., 2006: Effect of essential oil compounds and plant extracts on decay and termite resistance of wood. Holz als Roh-und Werkstoff, 64 (6): 455-461. https://doi.org/10.1007/s00107-006-0098-8.

16. Kuçuk, M., 2005: Türkiye'nin Doğal Orman Gülleri. Çevre ve İnsan Dergisi, Çevre ve Orman Bakanlığı Yayınları 3 (62): 22-31 (in Turkey).

17. Kuçuk, S.; Kurkçuoglu, M.; Baser, K. H. C., 2018: Morphological, Indumentum and Chemical Characteristics and Analysis of the Volatile Components of the Flowers of Rhododendron ponticum L. subsp. ponticum (Ericaceae) of Turkish Origin. Records of Natural Products, 12 (5): 498-507. http://doi.org/10.25135/rnp.50.17.11.070.

18. Lin, C. Y.; Wu, C. L.; Chang, S. T., 2007: Evaluating the Potency of Cinnamaldehyde as a Natural Wood Preservative. International Research Group Wood Preservation, Sweden. IRG/WP 07-30444.

19. Matsunaga, H.; Kiguchi, M.; Evans, P. D., 2009: Microdistribution of copper-carbonate and iron oxide nanoparticles in treated wood. Journal of Nanoparticle Research, 11 (5): 1087-1098. https://doi.org/10.1007/s11051-008-9512-y.

20. Onal, A., 2000: Doğal boyar maddeler (EkstraksiyonBoyama), Gaziosmanpaşa Üniversitesi Fen-Edebiyat Fakültesi Yayınları, No. 7. Tokat (in Turkey).

21. Ozen, E.; Yeniocak, M.; Goktas, O.; Alma, M. H.; Yilmaz, F., 2014: Antimicrobial and antifungal properties of madder root (Rubia tinctorum) colorant used as an environmentally-friendly wood preservative. BioResources, 9 (2): 1998-2009.

22. Pařil, P.; Baar, J.; Čermák, P.; Rademacher, P.; Prucek, R.; Sivera, M.; Panáček, A., 2017: Antifungal effects of copper and silver nanoparticles against white and brownrot fungi. Journal of Materials Science, 52 (5): 27202729. https://doi.org/10.1007/s10853-016-0565-5. 
23. Peker, H.; Atilgan, A.; Ulusoy, H.; Goktas, O., 2013: Usage opportunities of the natural dye extracted from acorn (Quercus ithaburensis Decaisne) in the furniture industry upper surface treatment. International Journal of Physical Sciences, 7 (40): 5552-5558.

https://doi.org/10.5897/IJPS12.479.

24. Pelit, H., 2017: The effect of different wood varnishes on surface color properties of heat treated wood materials. Journal of the Faculty of Forestry Istanbul University, 67 (2): 262-274. http://dx.doi.org/10.17099/jffiu.300010.

25. Prabhu, K. H.; Bhute, A. S., 2012: Plant based natural dyes and mordants: A Review. Journal of Natural Product and Plant Resources, 2 (6): 649-664.

26. Prabhu, K. H.; Teli, M. D.; Waghmare, N. G., 2011: Ecofriendly dyeing using natural mordant extracted from Emblica officinalis G. Fruit on cotton and silk fabrics with antibacterial activity. Fibers and Polymers, 12 (6): 753. https://doi.org/10.1007/s12221-011-0753-5.

27. Samanta, P., 2020: A review on application of natural dyes on textile fabrics and its revival strategy in chemistry and technology of natural and synthetic dyes and pigments. Intech Open. https://doi.org/10.5772/intechopen. 90038 .

28. Shah, V.; Dobiášová, P.; Baldrian, P.; Nerud, F.; Kumar, A.; Seal, S., 2010: Influence of iron and copper nanoparticle powder on the production of lignocellulose degrading enzymes in the fungus Trametes versicolor. Journal of Hazardous Materials, 178 (1-3): 1141-1145. https://doi.org/10.1016/j.jhazmat.2010.01.141.

29. Stevens, P. F., 1978: Rhododendron L. In: Flora of Turkey and the East Aegean Islands (Davis P. H. ed.). Edinburgh University Press. Edinburgh, UK, 6: 90-94.

30. Sogutlu, C.; Sonmez, A., 2006: Color changing effect of UV rays on some local wood species treated with various shielding agents. Gazi University Journal of the Faculty of Architecture and Engineering, 21 (1): 151-159.

31. Sonmez, A., 2005: Ağaç İşlerinde Üst yüzey İşlemleri (I) Hazırlık ve Renklendirme, 2. Bask1, Gazi Üniversitesi Teknik Eğitim Fakültesi, pp. 56-57. Ankara (in Turkey).

32. Tanaka, Y.; Sasaki, N.; Ohmiya, A., 2008: Biosynthesis of plant pigments: anthocyanins, betalains and carotenoids. The Plant Journal, 54 (4): 733-749. https://doi.org/10.1111/j.1365-313X.2008.03447.x.

33. Tascioglu, C.; Yalcin, M.; Sen, S.; Akcay, C., 2013: Antifungal properties of some plant extracts used as wood preservatives. International Biodeterioration \& Biodegradation, 85: 23-28. https://doi.org/10.1016/j.ibiod.2013.06.004

34. Temiz, A.; Yildiz, U. C.; Aydin, I.; Eikenes, M.; Alfredsen, G.; Çolakoglu, G., 2005: Surface roughness and color characteristics of wood treated with preservatives after accelerated weathering test. Applied Surface Science, 250 (1-4): 35-42. https://doi.org/10.1016/j.apsusc.2004.12.019.

35. Terzioglu, S.; Merey, N.; Ansin, R., 2001: A Study on Turkish Rhododendron L. (Ericaceae). Turkish Journal of Agriculture and Forestry, 25: 311-317.

36. Thevenon, M. F.; Tondi, G.; Pizzi, A., 2009: High performance tannin resin-boron wood preservatives for outdoor end-uses. European Journal of Wood and Wood Products, 67 (1): 89-93. https://doi.org/10.1007/s00107-008-0290-0.
37. Tondi, G.; Wieland, S.; Lemenager, N.; Petutschnig, A.; Pizzi, A.; Thevenon, M. F., 2012: Efficacy of tannin in fixing boron in wood. BioResources, 7 (1): 1238-1252.

38. Toshiaki, U., 2001: Chemistry of extractives. In: Wood and Cellulosic Chemistry. Marcel Dekker, Inc, New York, pp. 213-241.

39. Windeisen, E.; Wegener, G.; Lesnino, G.; Schumacher, P., 2002: Investigation of the correlation between extractives content and natural durability in 20 cultivated larch trees. Holz als Roh-und Werkstoff, 60 (5): 373-374. https://doi.org/10.1007/s00107-002-0314-0.

40. Yalcin, M., 2012: Determination the Effects of Some Commercial Wood and Bark Extracts Against Wood Decay Fungi and Insects When Utilized in Indoor Applications. Ph. D. Dissertation, Duzce University, Duzce, Turkey.

41. Yamaguchi, H., 2001: Chemically modified tannin and tannin-copper complexes as preservatives for wood. The International Research Group on Wood Preservation, IRG/WP 01-30271.

42. Yeniocak, M.; Goktas, O.; Aliyazicioglu, S.; Colak, M.; Yeniocak, S.; Ozen, E.; Ugurlu, M., 2017: Determination of the effect of liquid glass $\left(\mathrm{SiO}_{2}\right)$ on color stability of wood stained by natural dyes. Drvna industrija, 68 (4): 351-357. https://doi.org/10.5552/drind.2017.1707.

43. Yeniocak, M.; Goktas, O.; Colak, M.; Ozen, E.; Ugurlu, M., 2015: Natural coloration of wood material by red beetroot (Beta vulgaris) and determination color stability under UV exposure. Maderas. Ciencia y tecnología, 17 (4): 711-722. http://dx.doi.org/10.4067/S0718-221X2015005000062.

44. Yeniocak, M.; Goktas, O.; Ozen, E.; Colak, M.; Ugurlu, M., 2018: Determination of leaching features of wood surfaces colored by eco-friendly red beetroot (Beta vulgaris) extract. Wood Research, 63 (3): 443-454.

45. ***Anonymous, 1991: Bitkilerden Elde Edilen Boyalarla Yün Lifinin Boyanması. Sanayi ve Ticaret Bakanlığı, p. 167, Ankara (in Turkey).

46. ***ASTM D1413-99, 1999: Standard test method for wood preservatives by laboratory soil-block cultures. Annual Book of ASTM Standard.

47. ***ASTM D2244-16, 2016: Standard practice for calculation of color tolerances and color differences from instrumentally measured color coordinates. Annual Book of ASTM Standard.

48. ***TS 5563 EN 113, 1996: Wood preservatives-determination of the toxic values against wood destroying basidiomycetes cultured on an agar medium. Turkish Standard Institution.

\section{Corresponding address:}

Assoc. Prof. HUSEYIN PELIT, PhD.

Duzce University

Faculty of Forestry

Department of Wood Products Industrial Engineering 81620 Duzce, TURKEY

e-mail: huseyinpelit@duzce.edu.tr 